\title{
CONTRIBUTIONS OF KAMPUNG INGGRIS PARE AND ITS IMPLICATIONS FOR UNSKILLED MUSLIM MIGRANT WORKERS.
}

\author{
Helfi \\ Institut Agama Islam Negeri (LAIN) Bukittinggi \\ e-mail:helfibkt@yahoo.co.id
}

Submission: 12 April 2019

Revised: 25 June 2019

Published: 20 July 2019

\begin{abstract}
The advantages of becoming Indonesian Muslim migrant workers abroad (known as TKI) are likely under expectation. Most of the workers engage in the informal sector without proper skills. The income generated from them is marked as the second-largest income after the energy sector. Ironically, most of them are regarded as becoming unavailable to access all form of worker rights appropriately. This research is qualitative research that aimed to describe and analyse the problem which relates to the circumstance of the people of Kediri who have the hight interest of working abroad at informal sector mainly, but without proper skills. The establishment of Kampung Inggris (Village for Learning English) located in Pare, the district of Kediri in East Java offers the people of Kediri many business opportunities since many visitors come to spend their money and time to learn English in Kampung Inggris. It is a highly potential circumstance that can be managed to transform a new economic sector behind the existing sectors such as the existing agricultural sector. This research is qualitative in the form of field research which is narrated analytically descriptively. This study attempts to capture directly how inequality occurs in Kediri people who have a strong interest in becoming an informal worker who does not have adequate skills abroad. The development of English villages in Kediri Regency is a promising business space for indigenous people and other communities around Kediri. The presence of academic tourists to study English has become a prospective economic gap. Ranging from regional tours to culinary, from lodging to bicycle sports, from laundry to stationery. A local potential that has gone international to change the agrarian economy towards a skill-based economy with various subsectors that can be developed with various variants in it.
\end{abstract}

Keywords: Muslim migran worker, Unskill, Kampung Inggris, Local economic

\section{Abstrak}

Ngaung indahnya jadi Tenaga Kerja Indonesia (TKI) memang tidak semanis yang dirasakan. Terutama Tenaga Kerja Wanita (TKW) yang bergerak di sector informal tanpa skill yang memadai. Mereka dipuji negara karena dianggap penyumbang devisa yang signifikan. Uang yang mengalir ke Indonesia berada pada peringkat ke dua terbesar setelah devisa dari sector migas. Di negara sana, mereka dijajah lahir dan batin, tapi ketika meninggal, mereka "dibiarkan". Sebuah resiko yang tidak berimbang. Penelitian ini merupakan penelitian kualitatif dalam bentuk penelitian lapangan yang dinarasikan secara deskriptif analitis. Penelitian ini mencoba memotret langsung bagaimana terjadiny a ketimpangan dalam masyarakat Kediri yang mempunyai animo yang kuat untuk. menjadi TKI/TKW informal yang tidak memiliki skill memadai ke luar negeri. Perkembangan kampung Inggeris di Kabupaten Kediri menjadi ruang usaba yang menjanjikan bagi pribumi dan masyarakat lain di sekitar Kediri. Kehadiran wisatawan akademik untuk. belajar bahasa Inggeris menjadi celah ekonomi yang prospektif. Mulai dari wisata daerah hingga kuliner, dari penginapan hingga olah raga sepeda, dari laundry bingga alat-alat tulis. Sebuah potensi lokal yang telah go internasional untuk mengubah ekonomi agraris menuju ekonomi berbasis skill dengan berbagai subsector yang dapat dikembangkan dengan berbagai varian di dalamnya.

Kata Kunci: TKI Muslim, Non skill, Kampung Inggeris, Ekonomi lokal

\section{Background}

The opening of AEC (Asian Economic Community) in December 2015 offers a great opportunity for Indonesia to increase the economics sectors. Besides that, AEM presents threats for local residents. It is expected that the lack of proper skills among local people to face the free trade zone established through the implementation of AEM will make them unavailable to compete well. Farmers would be 
one of the most vulnerable communities during the implementation of AEM in later times. ${ }^{1}$.

Farmers have not been empowered well by the governments for a long time although the authorities have ruled by different parties several times. Many policies issued by the Government tends to put farmers into unfavourable conditions instead of offering advantages for them. It is hard to deny that the government is likely unavailable to protect farmers from the side effects of global foreign policies in the field of agriculture, even, to some extent, heads in the opposite direction; following the global trend which leads many farmers to experience any forms of bad economic condition. As a consequence of the circumstance, many farmers try to seek alternative occupations to improve their family wealth which is one of they are becoming TKI or Indonesian migrant informal workers abroad. Becoming TKI is widely known as one of the most popular solutions having by farmers even though the government already implements several strick requirements that are not easy by farmers to fulfil it. Data about the kind of occupations among people of several villages in Kediri such as Ngekok and Kranding already poof the previous statement? It is showed that being TKI in Malaysia is marked as the third most job occupied by local people after being the makers of tofu and tempeh and their-seekers ${ }^{3}$. The third so TKI

${ }^{1}$ MEA is part of the global economic policy of the economic sector in a more popular space with the acronym AFTA and NAFTA or the Batam authority, Sijori and others. It all leads to free market as part of trade and finance liberalization by letting market as price determinant. The efforts made by the neoliberal are minimised the role of Governments related to the Community economy. Mansour Fakih, Bebas dari Neoliberalisme (Yogyakarta: Insist, 2010), p. 7.

${ }^{2}$ Irdaf Irdaf, 'Mobilitas Pencarian Kerja dan Remitan: Kasus Desa Pojok Kabupaten Kediri, Jawa Timur', Berdikari: Jurnal Pengabdian Masyarakat Indonesia, 1.2 (2018), 105-12.

3 Zacky Nouval F, dkk, Petaka Politik Pangan Indonesia, Konfigurasi Kebijakan Pangan yang Tak Memibak Rakyat (Malang, Intrans Publishing, 2010), p. v in Malaysia. Implications of separation of husband and wife who left became the TKI, causing a $60 \%$ divorce caused by the disharmony of the family due to lack of communication both sides ${ }^{4}$.

According to Tirtosudarmo, Java island -a place with a high number of poverty and unemployed people- is considered as the largest supplier Muslim of TKI, followed by NTB and NTT. It is recorded in 2014 that 78.306 TKIs originated from East Java which is in detail 8.869 workers were from Ponorogo, 8114 were from Malang, 7.973 were from Blitar, 7.271 were from Banyuwangi, 6.723 were from Tulungangung, 6.723 were from Majalengka, and 4.570 were from Kediri, and the rest came from other areas in East Java ${ }^{5}$. Male workers dominated the number of TKI who work in Malaysia. On the contrary, female workers dominated the number of Indonesia workers in Saudi Arabia ${ }^{6}$.

New current TKI abroad of labour are not professionals who come from East Java, Kediri became a particularly large question mark, given a large number of potential areas that could bloat the family economy such as Kampung Inggris for example.

\section{Kediri in the Myths between Coincidence and the Fact as an Introduction}

The Duke of Jaya Baya already predicted the popularity of Kediri during the reign of Mataram found in Java language which plural is known to the local community. He revealed that "Tulung Agung dadi kedung, kediri dadi kali

4 Abdurrahman (Pare leader community), Interview \{Wednesday, 18 May 2016\}.

5 Riwanto Tirtosudarmo and Lilis Mulyani, 'Indonesia's Migrant Workers and Overseas Labor Policy 1', Jurnal Masyarakat dan Budaya, 15.November (2011), 1-19.

6 Eggi Sudjana, Melepas Ranjau TKI, Strategi Pemberdayaan Burub Migran (Jakarta: RM Books, 2009), p. 129. 
dan suroboyo dadi rowo"(will become water, Kediri will so time and Surabaya will so swamp) $)^{7}$.

This prediction than "justified" by looking at the reality, that the Foundation of the Tulung Agung of Supreme located in areas which serve as a reservoir of Wonorejo and air circulation for the community. The fame of Kediri region is represented by the Pare with Kampung Inggris icon ${ }^{8}$. While the predictions against Surabaya as the swamp proved to be with the advent of large mud sink areas that there were such Porong and Sidoarjo Mud popular with Lapindo.

The discussion in this paper certainly does not explain the causes of the emergence of factors Lumpur Lapindo in Surabaya and Wonorejo dam effectiveness in Tulung Agung, but looking at the figure of Kediri as an area that has the potential to local economic development in reducing the labour unskilled abroad Muslim as TKI or TKW ${ }^{9}$.

Manpower professional is not synonymous with the informal workforce totalling almost evenly matched with the formal workforce. In 2014, informal TKI constituted $42 \%$ of the total number of TKI (182.262 workers). Meanwhile, formal TKI constituted $58 \%$ of workers $(247.610$ workers $)^{10}$. The following table 1 which published by BNP2TKI (National Board for TKI affairs) shows the number of TKI from 2011 to 2014:

7 Abdul (Pare citizens), Interview \{Sunday, 1 February 2016.

8 Suzy Azeharie, 'Pola Komunikasi antara Pedagang dan Pembeli di Desa Pare, Kampung Inggris Kediri', Jurnal Komunikasi, 7.2 (2016), 207-23 <https://doi.org/10.24912/JK.V7I2.19>.

9 Anam Miftakhul Huda, 'The Identity of Javanese Women (The Study of Phenomenology Toward Indonesian Migrant Women Workers)', JARES (Journal of Academic Research and Sciences), 1.1 (2016), 61-72 <https://doi.org/10.35457/jares.v1i1.506>.

10 Riwanto Tirtosudarmo, 'The Indonesian State's Response to Migration', Journal of Social Issues in Southeast Asia, $14.1 \quad$ (1999), 212-28 $<$ https://doi.org/10.1355/sj14-1i>
Table 1. Placement TKI $2011 \mathrm{~s} / \mathrm{d} 2014$

\begin{tabular}{|l|l|l|l|l|l|l|}
\hline No & Years & $\begin{array}{l}\text { Aloca- } \\
\text { tion }\end{array}$ & $\begin{array}{l}\text { TKI } \\
\text { Formal }\end{array}$ & $\mathbf{\%}$ & $\begin{array}{l}\text { TKI } \\
\text { Informal }\end{array}$ & $\mathbf{\%}$ \\
\hline 1. & 2011 & 586.802 & 266.191 & 45 & 320.611 & 55 \\
\hline 2. & 2012 & 494.609 & 258.411 & 52 & 236.198 & 48 \\
\hline 3. & 2013 & 512.168 & 285.297 & 56 & 226.871 & 44 \\
\hline 4. & 2014 & 429.872 & 247.610 & 58 & 182.262 & 42 \\
\hline
\end{tabular}

Sources: Data Processing Subdit Puslitfo BNP2TKI $2014^{11}$.

Kediri is well-known as a place where many Indonesian workers are originated. Besides that, it is also famous for a place where many English educational institutions take place.

\section{Local Potential "Wasted" in his Own Land}

Pare is a part of Kediri Regency. However, Pare is better well-known compared to Kediri. From an agricultural perspective Pare is potential for agriculture since it has a cool climate. Almost all types of grains, vegetables and tubers can flourish in this area such as rice, carrots, chillies, sugar cane, beans, cabbage, cassava, and others. Besides that, Mahoni and Sangon are other kinds of plant that generate extra income for the local community since these plants are highly needed for the furniture industry ${ }^{12}$.

Before the exuberance of Pare as academic English tourist areas, local residents hung their agricultural sectors of economy and trade. Regional satellite education industry as a center of Pare is geographically not so spacious. This area is located on the main street of Brawijaya and roads such as Jalan

11 Although there is already an effort shift the TKI informal to formal, but shifting TKI it, have not been significant. Based on data for the year 2007, that placement of the TKI informal amounted to $78 \%$. However, there are clear differences between placement in Asia Pacific and the Americas to the Middle East and Africa. In the first quarter more on formal sector which is about $52 \%$ while in the second quarter as TKI informal as much as $98 \%$. See, Sudjana.

12 Wiwin Yulianingsih and others, 'The Involvement of Informal Sector Workers in Society Learning Activities at Kampung Inggris Pare Kediri', Journal of Social Studies Education Research, 9.3 (2018), 132 44 <https://doi.org/10.17499/jsser.29578>. 
Dahlia subsector, the Jalan Anyelir, Aster and so on. While these areas are relatively far from the heart of the English language courses. Society still makes agriculture as the mainstay of the economy ${ }^{13}$. For residents who have the economic potential of the sector commerce, they are thus out of the Pare with the way wanders. They work as vendors with different types of sales that are in need of the community. Part again glanced at the labour economics as mercenaries in foreign countries by being TKI or TKW.

Indonesia labour paying out of State initially caused not attractive to local citizens laid down their lives in the pertaining sector that is "what is". Poverty farmer then caused by their low education levels, higher agricultural costs and limitations of agricultural land which is considered as a factor, not the share supply and demand. Limitations of land recognized as one factor in the cause of the poverty of farmers, to the amount of land a farmer with narrow (gurem) only the year 1983, amounted to 40.8 per cent. The year 1993 increased to 48.5 per cent, and in 2003 again increased to 56.5 per cent ${ }^{14}$. Limitations of land continue to occur in 2013 , even in the appropriate to rise.

The opportunity to become Indonesian migrant workers is taken by many local people to increase their economic and social status ${ }^{15}$.

${ }^{13}$ M Dian Ruhamak and Budi Rahayu, 'Pengaruh Word of Mouth terhadap Purchase Intention Melalui Brand Image pada Lembaga Kursus Bahasa Inggris Dynamic English Course Pare', Ekonika: Jurnal Ekonomi Universitas Kadiri, $1.2 \quad$ (2017), 32-33 <https://doi.org/10.30737/ekonika.v1i2.14>.

${ }^{14}$ Mufid A. Busyairi, Republike Salah Urus Menguak Nasib Buram Petani Indonesia (Jakarta: PT Wahana Semesta Intermedia, 2008), p. 14.

15 According to Elly, there are several status obtained someone through struggle. These patterns usually takes place in the social structure has undergone a change from traditional patterns towards the modern. The more so in the structure of a liberal capitalist society with emphasis the freedom of individuals to achieve a goal. In a structure like this, more open social structures to improve the social status of such a struggle getting the education, employment, seniority and the economy.
As stated by Bejo (local resident) that most people in Pare who become Indonesia migrant workers in Malaysia were engaged as labours in the plantations, constructions, or in oil palm industries ${ }^{16}$. Although the wage was considered low according to Malaysian standard, they managed to get many Rupiah, thanks to the exchange rate between Malaysian Ringgit and Indonesian Rupiah So that, they are available to use the money for repairing their houses, acquiring lands and castles, and even for establishing a business. In addition to Malaysia, the community also became a State in Singapore, TKI Hongkong, and Japan.

Kediri as the homeland of many Indonesia migrant workers can be recognized from the record of remittance that provided by Post Office of Kediri ${ }^{17}$. According to Iskandar -the head of Post Office of Kediri- 4.202 remittances ( $\mathrm{Rp} 13.6$ billion) and 4.790 remittances ( $\mathrm{Rp} 16$ billion) are recorded, respectively, in January and March. It is expected to increase significantly in every Idul Fitri. He stated that the remittance increased by $30 \%$ on the last Idul Fitri in $2015^{18}$. The

The struggle to improve social status is commonly referred to with the achieved status. See Elly M. Setiadi, Pengantar Sosiologi, Pemahaman Fakta dan Gejala Permasalahan Sosial: Teori, Aplikasi, dan Pemecahannya (Jakarta: Kencana Predana Media Group, 2011), p. 432. 16 Mr. Bejo (English teacher in Pare), interview $\{$ Wednesday, 27 January 2016\}.

${ }^{17}$ Joko Sayono, Indah Wahyu Puji Utami, and Lutfiah Ayundasari, 'Migrant Workers and SocioEconomic Changes', Masyarakat, Kebudayaan dan Politik, 31.2 (2018), 176-89.

18 Another social effect that TKI have gained after returning from abroad is the occurrence of lifestyle changes, behaviors and orientation change towards more materialism. "New style" brought by migrant workers who return home from abroad also affects local youths to try their luck to be the next TKI. The income of TKI from the service sector is then sent to the Origin area called Remitan. Remitan can be an interest and bonding of residents to migrate from origin to other areas marked by the transfer of income or goods to the original area. Furthermore Remitan not only related to economic issues, but including ideas or skills that are in the country of outside. Remitan not only contributes to economic enhancement, but also affects the distribution of a region's development. Anggraeni Primawati, 
remittance mainly comes from the Middle East, Korea and several other countries in Asia ${ }^{19}$.

The majority of migrant workers originated from Pare is regarded as unskilled workers. Most of them just finished elementary and secondary education such as SD (elementary schools), SMP (junior secondary school) and SMA (senior secondary school). Even some of them did not finish their elementary education. This lack of education leads them to end up as labour. According to BNPTKI, there were 429.872 Indonesia migrant workers in 2014. In terms of education, graduates of elementary schools constituted $32.29 \%$ of workers (138.821), of junior high schools constituted $37.86 \%$ of workers ( 162.731), of senior high schools constituted $24.85 \%$ of workers (106.830), of diploma constituted $4.04 \%$ of workers (17.355), of university constituted $0.92 \%$ of workers (3.956) and of postgraduate constituted $0.04 \%$ of workers $(179)^{20}$.

The growth of business in the form of the establishment of many English educational institutions in Pare does not improve the ability of many local people in using English. In other words, local people do not utilize educational activities to acquire English as one of their communication skills. Many of them just take the economic advantages from the circumstances, generating income from many visitors who come here to learn English. The

'Remitan Sebagai Dampak Migrasi Pekerja ke Malaysia', Sosio Konsepsia, 16.2 (2017), 209-22. See also, SE Sili Antari, 'Pengaruh Pendapatan, Pendidikan, dan Remitan terhadap Pengeluaran Konsumsi Pekerja Migran Nonpermanen di Kabupaten Badung (Studi Kasus Pada Dua Kecamatan Di Kabupaten Badung)', Piramida, 4.2 (2008), 20-35.

19 Anonim, 'Remitansi TKI Melalui Kantor Pos Kediri' < http://www.antarajatim.com. remitansi-TKImelalui-kantor-pos-kediri naik 30 persen $>$ \{accessed 10 October 2017\}.

${ }^{20}$ Anonim, 'Penempatan TKI tahun 2014, <http://www.bnp2tki.go.id/9801/thn-2014 BNP2TKImencatat-penempatan-TKI-tahun-2014 $>$ a accessed 4 March 2016\}. income comes from several kinds of local businesses such as accommodations, culinary or stationery suppliers. According to Rindu -an English teacher at one of the English colleges in Pare- the local people do not see learning English as an opportunity to increase their properties $^{21}$.

Puslitfo BNP2TKI noted, throughout the years of 2014 placement TKI as much as 429,872 the man, the highest from 25 countries are Malaysia; 127,827, Taiwan 82.665, Arab Saudi 44.325, Hong Kong 35.050, Singapura 31.680, Oman 19.141, Uni Emirat Arab (UEA) 17.962, Korea Selatan 11.848, Brunei Darussalam 11.616, United States 9.233, Qatar 7.862, Bahrain 5.472, Jepang 2.428, Kuwait 1.714, Itali 1.295, Turki 1.246, China 915, Fiji Islands 902, Spanyol 889, Mauritius 838, Canada 830, Netherlands 796, Thailand 717, Australia 644, dan Afrika Selatan 587. While the rest as much as 11,390 TKI scattered in various States of other placement ${ }^{22}$.

Most of the women migrant workers who sent abroad are not well-educated. The lack of skills makes them ended up as house assistant in their host countries. The low education level makes them not available to fully understand their working rights or to deal with administrative issues ${ }^{23}$. According to Valian Budi, this circumstance put many of them to several problems such as getting overworked and extremely underpaid, experiencing sexual harassment, and even becoming murdered. It is ironic since in Indonesia they are regarded as a party that most contributed to strengthening the IDR through the remittance ${ }^{24}$.

${ }^{21}$ Mrs. Rindu (English teachers in Pare), Interview \{Tuesday, 2 February 2016 .

${ }^{22}$ Anonim.

23 Prihatini Ambaretnani dan Selly Riawanti, Upaya Meningkatkan dan Melindungi Kesehatan Reproduksi TKIW (Yogyakarta: Galang Press, 1999), p. 25.

24 Valiant Budi, Kedai 1001 Mimpi, Kisah Nyata Seorang Penulis yang Menjadi TKI (Jakarta: Gagasmedia, 2011), p. 12. 
Some English colleges in Pare already perform to help the local people to learn English by providing a program in which the local people may come to learn English free of charge. ELLA Course and Krishna are among colleges that provide free of charge English education for local people. It is recognized from their advertisement brochure in which acknowledged there free tuition fee for local people in accessing an English course provided by ELLA Course. The same efforts are also undertaken by Global English Course, Krishna and others. learn without paying the course fee for local residents as the moral sense of their impact on indigenous peoples, in which institutions grow and develop courses in the area of the original natives.

Some areas of the course that delivers cost study apply to all ages, ranging from junior high school, high school, college even anyone who wants to learn. Based on the recognition of some tutors English, no locals who want to learn in their own hometown. Natives prefer to be TKI or TKW abroad ${ }^{25}$. According to $\mathrm{Mr}$ Tarjo for example, the number of relative plenty of Kediri TKI. The income they receive is sent to hometown to build a House or used in any other form as "savings" after not so TKI again at a later date.

\section{Industrial Development in English Language Education}

The cost of study in English is very affordable. By paying Rp 43.000 once my access an 12-meeting learning program which is means a student just need to pay about Rp 3.584 for a single meeting. The payment is a single payment, the student does not need to pay for hidden costs such as payment for registration fee or administration fee. If an institution managed to attract 25 students to come for a course, it means they collect Rp 1.075.000 from the course. The money will be used to cover

\footnotetext{
25 Mrs. Rindu (English teachers in Pare), Interview \{Tuesday, 2 February 2016\}.
}

operational costs such as spending for administration cost, building rent, and learning modules.

If one local 25 students, then Rp 43,000 X 25 students $=\operatorname{Rp} 1.075 .000 /$ local . The amount of income distributed to administration costs, rental building, doubling the module and others.

The cost of the program already mentioned above without registration fees, without the cost of development, without the exam fee and without money certificates. Entirely contained within the cost of the program for 15 days with a time of effective learning 10 face-to-face plus one midterm and final exam of the semester. The duration of the learning that usually begins 15 days from Monday to Friday. Saturday and Sunday as part of a holiday as in the other colleges. Not surprisingly, local used as learning also has a diverse quality, ranging from the magnificent permanent accounts until such local goat enclosure is not so. Even learning done in the corner of a building or under a tree with a potluck. According to the Chairman of the institution's courses, the quality of the standard that must be maintained in spite of its limited means. Survivalnya institution, of course, sees how they maintain the quality instead of facilities $^{26}$.

There is a standard non-written agreement among existing English institutions that there are two kinds of programs of English learning; a program with 10 meetings in a month and 25 meetings. While the first kind of program is regarded as a regular program among the institutions, the 25-meeting program is usually conducted based on a request from participants.

26 Endang Haryanto, 'Teacher s' Corrective Feedback on Students' Pronunciation at the Daffodils English Course Kampung Inggris Pare Indonesia', Linguists: Journal of Linguistics and Language Teaching, 2.2 (2015), 23-34. 
The development of each course institution also varies, for example, Global English, for example, in the 25th period of January 2016, he was able to receive 151 local members for two weeks of study time ${ }^{27}$. Cost for rent is calculated every month, even though the participant only used the facility for two weeks. Cost for rent is calculated every month, even though the participant only used the facility for two weeks. 4 students occupy one dorm room with the size of $4 \times 4$ M2. If one program is combined with a dormitory, then the cost that must be spent by the student is IDR 825,000 / person. If each local contains an average of 25 students and one program costs, for example, IDR 405,000. Then 25 local $\mathrm{X} 151$ students $=3775$ students. If $3775 \mathrm{X}$ $405,000-=1,528,875,000$. If $1,528,875,000,-\mathrm{X} 2$ $($ period 10 and 25$)=3,057,750,000$. This amount is a very fantastic number in one month, especially if added with the rental of camp provided by the Global English institution for students. The following is the program offer and the local number on the Global English Course for the 25th period of January 2016 as the table 2 follows:

Table 2. Program of Global English Course

\begin{tabular}{|l|l|l|l|}
\hline No & \multicolumn{1}{|c|}{ Item } & No & \multicolumn{1}{|c|}{ Item } \\
\hline 1. & Speaking I: 17 local & 13. & $\begin{array}{l}\text { Listening IELTS: } \\
3 \text { local }\end{array}$ \\
\hline 2. & Speaking II: 8 local & 14. & $\begin{array}{l}\text { Fun Reading: 1 } \\
\text { local }\end{array}$ \\
\hline 3. & Speaking III: 2 local & 15. & Writing I: 3 local \\
\hline 4. & Vocabulary I: 16 local & 16. & Writing II: 1 local \\
\hline 5. & $\begin{array}{l}\text { Vocabulary II: 10 } \\
\text { local }\end{array}$ & $\begin{array}{l}\text { Vocabulary III: 2 } \\
\text { local }\end{array}$ & $\begin{array}{l}\text { Writing IELTS: 2 } \\
\text { local }\end{array}$ \\
\hline 6. & $\begin{array}{l}\text { Pronunciation I: 18 } \\
\text { Local }\end{array}$ & 19. & $\begin{array}{l}\text { Lramer } \\
\text { Writing: 5 local } \\
\text { TOEFL: 7 local }\end{array}$ \\
\hline 8. & $\begin{array}{l}\text { Pronunciation II: 2 } \\
\text { local }\end{array}$ & 20. & $\begin{array}{l}\text { Gramer } \\
\text { TOEFL: 8 local }\end{array}$ \\
\hline
\end{tabular}

27 Az Sugeha, 'Students'Motivation on Learning English At Toefl Program of Elfast English Course in Pare', Jurnal Ilmiah Mahasiswa FIB, 2.2 (2015), 45-59 $<$ http://jimbastrafib.studentjournal.ub.ac.id/index.php/ jimbastrafib/article/view/907>.

\begin{tabular}{|l|l|l|l|}
\hline 9. & Gramer I: 14 Local & 21. & $\begin{array}{l}\text { Reading for } \\
\text { TOEFL: 5 Local }\end{array}$ \\
\hline 10. & Gramer II: 5 Local & 22. & IELTS: 1 local \\
\hline 11. & Fun Listening: 2 local & 23. & Reading: 1 local. \\
\hline 12. & Listening: 3 Local & & \\
\hline
\end{tabular}

Source: Committee of Global English, Register Name and Local Distribution in January 25, 2016.

\section{Recruitment of New Members as Economic Opportunities}

Institutions apply different ways to attract new students. Starting manually or in a modern way. The manual system is done by implementing a system operational procedure (SOP). There are clear criteria for the teacher, the method used, the origin of the institution, the recruitment system for tutors and textbooks distributed to students. The SOP is very important to ensure the quality of graduates A manual system is also used to attract members by inserting socialization of institutions during class meetings. The target to be achieved is, if the alumni have returned to their respective areas of origin, they can bring relatives, friends or anyone who needs further development of English. Word of mouth marketing is a more effective tool in recruiting new students to come to Pare. Dian a student who comes from Kalimantan- said that recommendation that she got from her friend who already finished an English course in Pare influenced her in many extents regarding her decision to come to Pare and choose institution when she is learning English.

Many English educational institutions take the advantages of this kind of advertisement. In addition to word of mouth, social media and internet platforms are also used for branding. Besides the two previous ways to attract and recruit new students, the institutions also relied on marketers.

The new recruitment model initiated by other course institutions to attract members is the brokerage system. This form can also be classified into two groups, first, brokers who are assisted by technology skills through internet media. Second, a manual broker. 
The first form with the help of an intermediary ad agency. This institution put the name of a certain institution in the initial information of the internet after consumers typed English villages, pare on the Google bar. If this is typed, the first one that comes out is an institution that has been promoted by an intermediary by placing the name of a particular course institution at the top. Course institutions that have paid to brokers will be connected to all institutions that have paid "fear money" to brokers with sequential systems. This system also includes the name of the course institution, the period offered, the program, the cost of the course, and the camp. All this information can be accessed with internet media through processing carried out by the broker. The institutions should pay the marketers Rp 50.000 for every single student who registers after their recommendation. Commonly, only expensive institutions apply this marketing strategy.

The second form is to make all alumni as workers or anyone who is able to bring each member into a particular institution in return for parenting. Every alumnus or anyone registered is considered a worker with proof of membership card from the course institution. They get a "salary" of $10 \%$ for each member brought and registered with a course institution. This was done by the Brilliant Course. If the course costs one million, then the broker will get one hundred thousand for each new student registration.

For British village areas, the second model is used by transportation services that deliver registrants from motorcycle taxi drivers, travel agents, alumni or anyone who offers new members on the Brilliant Course. The brokerage system initiated by Brilliant Course is considered beneficial to local residents to get additional income in addition to their main work as motorcycle taxi drivers, drivers, pedicab drivers, or anyone who is able to bring prospective new members to the Brilliant Course institution $^{28}$.

\section{Multi-level Marketing Method in Creating Job Opportunities}

Teachers of "Pare schools" come from the Pare institution itself. Students studying at Pare are recruited then after the independent gives them the freedom to set up their own course. This learning model is an example of a father's success in developing children to be able to be independent. Mister Kalan was considered the pioneer of the development of Pare as a centre for learning English in 1976. The first English colleges established in Pare is BEC (British English Course) and it is still in operation. Interestingly, alumni of BEC managed to perform better English learning system in their own institutions through better implementation of several principles of foreign language learning which include the use of appropriate teaching method and learning media. English institutions in Pare managed to show Indonesia and the world that they are fully capable to help students acquiring English skill through transforming their institutions to become a fun learning English environment.

The system of dividing in developing English language courses can be proven from several reasons; first, there was recognition among the Pare alumni themselves that they did initially study at one of the Pare course institutions, then after graduation, the alumni opened their own course institutions. Secondly, there are similarities in learning themes at a one-course institution with other course institutions. Like the Junk Food theme on speaking I on the English Course, it is the same as the theme for vocabulary II on the Mahesa Course and in other course institutions.

${ }^{28} \mathrm{Mr}$. Oki Yosevi (English teacher), Interview \{Wednesday, 10 February 2016\}. 
As said by Azizh -one of Para graduatesthat she has been an English teacher in Pare for 6 months. She was hired for the 10 months of teaching and can be extended of the next ten months. If you disagree for an extension, you may take opportunities to teach at another English colleges in Pare, or even work in a different kind of employment. All choices are left entirely to the tutor's individual. New English teachers or tutors get paid half what senior tutors can make. They get paid twice a week including an annual bonus payment. The rate of wages is based on the number of daily meetings. According to the confession of Azizah, before going to teach, he was placed at the Clinic's teacher for 6 months with various capital needed to teach. If interested, the teacher can apply to become a teacher by making a cover letter. Then took the test in the form of structure, speaking, and teaching practice or micro-teaching ${ }^{29}$.

There are three positions commonly found in English colleges in Pare; tutor, teacher, and teacher with additional jobs. Tutor act as a teacher assistant in a class. Potential graduates are commonly recruited as tutors in a college in which they finished their English learning. While a teacher focuses on learning activities, a teacher with additional jobs usually is responsible for managerial activities, as well as administration, besides teaching as a regular activity. In terms of salaries and wages, each position gets paid differently. They teach is considered as a popular teaching and learning person in terms of microteaching or assistant. The institution does not pay them and some of them get a fee from students who want to get special services such as private English with a nominal "sincerity". Potential tutors can be promoted as teachers after passing several tests. In some course institutions such as Krishna, for example, tutors are part of the

29 Mrs. Azizah (English teacher), Interview \{Tuesday, 2 February 2016$\}.$
English learning process on a 2-month program called the Planet program.

According to Ismail, the teacher gets a salary based on the number of locales they teach. The lowest salary given is Rp. 800,000 to Rp. 2,000,000 per month. Teaching time almost spent all of their afternoon time transferring English to students. Starting at 5:30 a.m. until 6:00 p.m. with a variety of hours $^{30}$.

While teachers with positions, in addition to their teaching, also get additional assignments as managers of course institutions. They can be regarded as a manager, teacher, as well as the principal. The salary they get starts from 2,100,000 / month or more.

\section{The Role of the Kampung Inggris in Reducing TKI Moslem Abroad}

The reputation of Kampung Inggris as an English learning center in Indonesia can be recognized from daily routines that occur over there. Soon after Fjar Prayer (4.30 am), student activities begin and continue until midnight. Streets are usually becoming crowded in the morning when students and visitors commute from their dorms and hostels to the colleges. A similar situation also happens at 11.30 am during break times and at $4.00 \mathrm{pm}$ after classes are finished. In the evening, particularly after sunset- students go food stalls, café, or shopping centers to having dinner, conversations, and leisures.

The high enthusiast to visit Pare and lear English there make the number of visitors in Kampung Inggris outnumbered the villagers. In many extents, this circumstance improves the local economy. Pare is not only visited by students but also by many people who are interested to engage in businesses in Pare. They run businesses in many areas of business such as culinary, books and stationeries, laundry services, fashion, and travelling agency.

$30 \mathrm{Mr}$. Ismail (English teacher), Interview \{Tuesday, 13 February 2016\}. 
Brawijawa Street in Pare is one of the places where the visitors run their business since it is highly marketable. In another extent, local people start to think that visitors who run business in Pare lead them left out and pushed down economically. English villages like sugar surrounded by ants. Not only educational tourists, but immigrants with their various skills also try their luck in the English village. Such as food traders, clothing merchants, fruits, shoe soles, and travelling buskers. Looking at the British village as one of the industrial lands, many immigrants complain about Pare. Immigrants than indigenous people more dominate the main road of the English village in the form of Brawijaya Street. Migrants carry out various economic activities such as selling clothes, stationery, books, food and so on. They come from Surabaya, Bandung, Sulawesi, Jokja, Jakarta and others.

Residents benefit from "accidentally" from the advantages of English teaching methods. Indigenous land rose significantly following the pace of demand and availability. The price of land that used to be cheap became expensive, houses that were once only one level to two levels, stalls that were once quiet became crowded, bicycle rentals were scattered everywhere, and so on. Local people have anticipated economic development by looking at the potential in their area. Indigenous people open various stalls that sell various needs of migrants - ranging from small scale to significant capital. Such as adding boarding rooms to contract, making cafes from the small to the class of restaurants at "wholesale" prices, from mini markets to retail gasoline sellers, from clothing to bicycle shops, motorcycle taxi drivers to branded travel to all destinations and so on. According to Mrs Rindu, local residents protect their economic sustainability by banning the establishment of supermarkets or minimarkets that do not belong to indigenous people. Not found in English mini-market villages such as
Indomaret, Alfamark or the like starting from the main road; Brawijaya reaches the sector roads in the English village. Indigenous people manage their economic potential independently by utilising land, houses, stalls, and others for the benefit of indigenous people.

Prices offered for accommodation are varied depend on facilities. The prices are ranging from Rp. 120.000 to Rp. 700.000. A single room is available for up to four persons. According to Syafi'i, who has a wife from the English Village, it was revealed that the bags of migrant workers beside Kediri were from the Tulung Agung and Blitar areas. Especially rural areas far from urban areas. They consist of women who work as housemaids, baby sitters, and elderly nurses. Of the several jobs available, elderly nurses dominate more than other workers ${ }^{31}$. Countries that are the destination of female workers such as Hong Kong, Korea, and Singapore. Job training before leaving abroad is facilitated by the PJTKI provided by the Kediri government. From the aspect of language acquisition, they also did not make the English village a place for referral language training. Language courses provided by the local government for migrant workers in obtaining English capital.

As for the Pare area itself, Man takes the biggest proportion of Indonesia migrant workers. Most of them are considered unskilled labours. Malaysia as the host country for Indonesian migrant workers- does not require an English requirement due to the similarity of language between Malaysia and Indonesia. Meanwhile, finding job opportunities in Korea, Hongkong, and Japan, necessarily needs English skill. The closeness of Malay language with Indonesian has become a separate factor so that they don't need to get

\footnotetext{
${ }^{31}$ Moh. Sulhan, 'Nilai Profetis Pendidikan Islam Untuk Menanggulangi Perdagangan Manusia', Nadwa, 6.2 (2016), <https://doi.org/10.21580/nw.2012.6.2.585>
} 
English language training such as preparation of female labour for the regions of Korea, Hongkong, and Japan ${ }^{32}$.

The more variation form of work for TKW was explained by Prihatini and Selly, that Malaysia, Singapore, and Hong Kong needed workers in the field of pre-school childcare, use of elevators and escalators, car washing, nursing care, pick-up and learning assistance for school children, parenting and baby care, animal care, use and maintenance of electrical appliances, reception of telephone and garden maintenance ${ }^{33}$. If the local population has little English skills, they can find better jobs, while at the same time a more promising level of well-being both at home and abroad. Job seekers can use the internet by typing jobseekers on the Google bar, then selecting the overseas jobs option in the more ways to find jobs column. Then copy overseas jobs. Finally, choose the destination country and the number of jobs available ${ }^{34}$.

The outstanding work opportunity for the development of British villages is the number of course institutions. Establishment of a new English college in Pare needs a different kind of employment such as teacher, offices staff, security, and parking attendants. There are no special requirements, including the burdensome requirements for the establishment of course institutions provided in the English village ${ }^{35}$. According to the statement, Pak De, a native, Tulung Rejo explained, Everyone can start their own English colleges. All you need to do it is

32 Mr. Syafi'i, (English teacher), Interview \{Thursday, 4 February 2016\}.

${ }^{33}$ Ambaretnani dan Selly Riawanti.

34 Another step to search jobs through the internet is by typing jobstreet.com then writing Japan to appear latest jobs posted. Then chosen according to the desired job. See Jubilee, 101 Tip \& Trik Mencari Kerja Online (Jakarta: PT Elex Media Komputindo, 2008), p. $10-18$.

35 Finna Dwi Prastiwi, 'The Study of Teacher Talks Used By English Course Teacher of Pare-Kediri in Speaking Class', RETAIN, 3.1 (2006), 1-5. budget and English teaching skills. The important thing is the consideration for $\mathrm{Mr}$. Kalend ${ }^{36}$, as elderly as English. " According to Mr. Kalend himself, who was told by Pak De "Let nature do the selection of the quality of the course institutions, A good institution will sustain, while the poor one will fall. Based on Pak De narrative, the number of courses in English villages in 2014 was more than $120^{37}$ institutions with various programs and various facilities that they had $^{38}$

Now, there is a decline in informal TKI abroad. There are at least three factors behind it; First, there is an improvement in the placement of Indonesian migrant workers in several countries in the Middle East. The postponement of the placement (moratorium) of informal TKI working (in the Household Management sector) in 6 countries, namely: Kuwait, Jordan, Syria, Saudi Arabia, Qatar, and the United Arab Emirates (UAE). The

$36 \overline{\text { Muhammad Kalend comes from Kutai }}$ Kartanegara who became a students in Modern Gontor Cottage, Ponorogo, East Java. But in the fifth year when in Gontor, he left the hut because he could not afford the tuition fee to complete the education. Through the advice of his friend that there is a teacher who is intelligent and mastered 8 languages in Pare village named Achmad Yazid. Kalend then studied to Ahmad Yazid in hopes of being able to master at least English and Arabic. The popularity of Mr. Kalend as an English teacher was actually socialized by two students of IAIN Sunan Ampel Surabaya who successfully graduated from the state exam after studying for 5 days with Mr. Kalend because Achmad Yazid has a need to Majalengka at the time. Information from the mouth of Kemulud then become Emrio the formation of local English learning first until the formation of the English Kursur called Basic English Course (BEC). The inauguration of the Institute of the BEC course was conducted on 15 June 1977 with a total of 6 students. Suzy Azeharie. According to Kusnul Dwi Anitasari, Achmad Yazid was actually a prominent scholar and was a guide to Clliford Geert while conducting research and writing a book that titled The Religion of Java. Kusnul Dwi Anitasari, Dari Desa Menjadi Kampung Inggris (Kajian Sejarah Perekonomian Desa Tulungrejo Pare Kediri 1977-2011 (Malang, UM Press, 2013), p. 1.

37 Even according to Suzy Azeharie that the English language course in pare is amounting to 150 institutions. See Azeharie.

${ }^{38} \mathrm{Pak}$ De, (Pare citizen), Interview \{Wednesday, 2 February 2016\} 
enactment of the TKI moratorium in these countries is because the local government does not guarantee protection to TKI. Second, the implementation of tightening the placement of Indonesian migrant workers with the duration of training is evidenced by the fingerprint system. Third, the reduction of Indonesian migrant workers interested in the Indonesian unskilled category. According to Mr Hidayat, the Government has gradually continued to suppress the number of informal TKI placements, especially for TKI because they are vulnerable to problems. TKI usually live in the same house as users of more than one person, such as parents, children, in-laws, and even other families ${ }^{39}$. Bicycle Rental is One Example of Local Economic Power Relations

Bicycles are chosen as local transportation for course students considering the English learning centre in Pare is relatively close. The program offered by the course institution is sometimes not equipped with other facilities. Like the place of the course not designed close to the inn or camp. Students must look for alternative lodging with varying distances, starting from a distance of one kilometre to three kilometres. Furthermore, an English language program is also not centred in one location, such as taking the TOEFL program, for example, learning is conducted at the Brawijaya head office, but additional programs are placed in Alas Roban, which is about one kilometre west of the central office. Additional learning is also placed in the Corner Cafe which can also be reached by bicycle. The distance between the course office and the place of the study also occurs in other programs and at different courses in the Pare area.

Local residents initiated the inspiration for the use of bicycles for the Kampung Inggris

${ }^{39} \mathrm{Mr}$ Hidayat, (English teacher), Interview \{Saturday, 2 February 2016\}. area according to Mrs Rindu. ${ }^{40}$ Popularising bicycles as a means of transportation is a striking attribute in the Kampung Inggris, considering that Pare is a very useful small city by bicycle. Bicycles are also considered vehicles that do not cause congestion, are easy to carry, environmentally friendly, efficient, and healthy.

It is very easy to find bicycle rentals in the Kampung Inggris, starting from the narrative form, competitive prices, and cheap guarantees. Bicycles offered include historic ontel bikes, romantic relaxing bikes, elegant sports bikes, feminine women's bikes and so on. The price of bicycles is also offered at an affordable price within a month. Like a relaxed bike, for example, prices offered range from 70,000 . to $100,000 /$ month. Sportbikes without inner tube are offered from Rp. 100,000 to 170,000 per month. Feminine pink bicycles are priced at 70,000 to 120,000 per month based on the quality of the bike, whether it's new or old ${ }^{41}$

Consumers who are interested in renting bicycles are enough to make their identity as collateral such as a KTP, SIM or student card. Rugged bikes are also equipped with a key for safety. If a bicycle is damaged or lost when in the hands of the borrower, the bicycle owner usually asks to replace it based on the applicable provisions. ${ }^{42}$

Owner bikes usually give their own attributes as the identity of the bicycle owner. Long-range bicycles have certain codes that are affixed to a bicycle plate or clutch (zinc which serves to protect users from splashes of water located on the rear wheels). The bicycle codes used like JMA No. 43 A, BM No.4, STER No. 40, ILA No. 47, FS No. 24 and so on. The bicycle owner also printed the bicycle as an

40 Mrs. Rindu (English teachers in Pare), Interview \{Thursday, 28 January 2016\}.

${ }^{41} \mathrm{Mrs}$. Rindu (English teachers in Pare), Interview \{Thursday, 28 January 2016\}

${ }^{42}$ Mr. Muhsin, (English teachers in Pare), Interview (Friday, 29 January 29, 2016 . 
identity on the bicycle plate with the words "Ojo Dumeh"

\section{Foreign Workers in Kampung Inggris}

Another unique figure in the Kampung Inggris is a large number of foreign nationals who work in Indonesia. Among them are working as English teachers with various programs offered. Like the Bule House English Course for example. They teach several English subjects such as vocabulary, pronunciation, speaking, and public speaking. They are available for the private class as well. Duration of study is also offered for two weeks or one month. Learning can also be done regularly, privately or full day plus camp. The price offered starts from Rp. 80,000, - for two weeks to 900,000 , for a period of one month.

Behind hiring native speakers to teach professionally, involving tourists is another way to get a native as an English teacher. Besides that, a foreigner who married local people is usually willing to teach English in any institutions in Pare.

The first recruitment system is carried out by offering European citizens to teach in a one-course institution. Selection is made by looking at participants' curriculum vitae who are interested in teaching. This institute of courses with recruitment systems prioritizes the quality of westerners in English language learning rather than merely utilizing tourist "moments" when visiting Indonesia. This system is carried out by the Global English course institute with special local speaking with Bule (European citizens) programs. Consumer costs are more expensive than the costs of domestic tutors ${ }^{43}$

Second, by utilizing foreign tourists visiting Indonesia. Such a system is carried out by contacting tourists who have taught at Pare or by recruiting them when students are taken

\footnotetext{
${ }^{43}$ Mrs. Rindu (English teachers in Pare), Interview \{Friday, 29 January 29, 2016\}.
}

on excursions while practising English directly. Places that are targeted for practice such as the Jakarta area with its Borobudur Temple. The tutor team then offered them to teach in Kampung Inggris, complete with fees and facilities provided for them. Teaching time and length of stay as a teacher have been determined. Starting from a matter of days to a matter of weeks. The presence of native speakers for the course institutions is the main attraction for developing business in attracting consumers as done by Brilliant Course. ${ }^{44}$

The third form with the marriage of Indonesian citizens with foreign nations then opened a course institution in the Kampung Inggris. Foreign teachers who open courses in Pare by utilising Indonesian work visas such as Bule Hause institutions for example. Actually, the founders of the course institutions came from Blitar who tried their luck in the English business. According to Pak De, the number of courses available in English in 2014 was more than 120 institutions with various programs and various facilities that they had. They contracted the homes of local residents to develop the English language education industry 6 months ago

The diversity of potential possessed by Kampung Inggris opens up opportunities for indigenous people or residents of Kediri more broadly to improve the family economy. Pare is considered a promising alternative economic destination, compared to informal TKI with limited skills. Adagium said, "Rain in our country, golden rain in the land of people, better be in our area".

The concrete step of empowering TKW by BNP2TKI Kediri is by empowering integrated former TKI/WNI/ and their families with a food security program, creative economy industry, tourism industry, and

${ }^{44} \mathrm{Mr}$. Oki (English teachers in Pare), Interview \{Wednesday, 10 February 2016\}.

45 Pak De, (Pare citizen/worker), Interview $\{$ Wednesday, 2 February 2016\}. 
service industry in 2015. This activity is able to encourage the growth of alternative economies for the population local level in fostering the family economy for the Kediri area and its surroundings $\mathrm{s}^{46}$.

\section{Conclusion}

Working abroad for the Indonesian people is not considered foreign anymore because there is a culture of certain regions that support for migrants such as those found on the island of Bawean in East Java and Minangkabau in West Sumatra. The business of migrating from the aspect of history has also been going on for a long time, even before the entry of the Dutch into Indonesia.

The development of the Kampung Inggris for academic tourists needs to be taken into consideration, especially for local people or surrounding areas so as not to depend on the fate of TKI. The miserable screams of TKW in the informal sector who did not equip themselves with special skills became an irony in the midst of many alternative jobs that could be created domestically. It is necessary to intervene with the local government to encourage the creation of alternative workspace for prospective and sustainable Kediri communities.

\section{References}

\section{Books}

Ambaretnani, Prihatini and Selly Riawanti, Upaya Meningkatkan dan Melindungi Kesehatan Reproduksi TKIW (Yogyakarta: Galang Press, 1999)

Anitasari, Kusnul Dwi, Dari Desa Menjadi Kampung Inggris Kajian Sejarah Perekonomian Desa Tulungrejo Pare Kediri 1977-2011 (Malang, UM Press, 2013)

Budi, Valiant, Kedai 1001 Mimpi, Kisah Nyata Seorang Penulis yang Menjadi TKI Jakarta: Gagasmedia, 2011)

${ }^{46}$ Eni Sri Rahayuningsih, 'Analisis Pengelolaan Tenaga Kerja Indonesia (TKI) Di Jawa Timur', Media Trend, 1.2 (2016), 35-48.
Busyairi, Mufid A,. Republik Salah Urus Menguak Nasib Buram Petani Indonesia Jakarta: PT Wahana Semesta Intermedia, 2008)

Fakih, Mansour, Bebas dari Neoliberalisme (Yogyakarta: Insist, 2010)

Jubilee, 101 Tip \& Trik Mencari Kerja Online (Jakarta: PT Elex Media Komputindo, 2008)

Nouval, Zacky F., dkk, Petaka Politik Pangan Indonesia, Konfigurasi Kebijakan Pangan yang Tak. Memibak Rakyat (Malang, Intrans Publishing, 2010)

Setiadi, Elly M., Pengantar Sosiologi, Pemahaman Fakta dan Gejala Permasalahan Sosial: Teori, Aplikasi, dan Pemecabannya (Jakarta: Kencana Predana Media Group, 2011)

Sudjana, Eggi, Melepas Ranjan TKI, Strategi Pemberdayaan Burub Migran (Jakarta: RM Books, 2009)

\section{Journals}

Azeharie, Suzy, 'Pola Komunikasi Antara Pedagang dan Pembeli di Desa Pare, Kampung Inggris Kediri', Jurnal Komunikasi, 7 (2016), 207-23 <https://doi.org/10.24912/JK.V7I2.19>

Haryanto, Endang, 'Teacher s' Corrective Feedback on Students Pronunciation at the Daffodils English Course Kampung Inggris Pare Indonesia', Linguists: Journal of Linguistics and Language Teaching, 2 (2015), $23-34$

Huda, Anam Miftakhul, 'The Identity of Javanese Women (The Study of Phenomenology Toward Indonesian Migrant Women Workers)', JARES (Journal of Academic Research and Sciences), 1 (2016), $61-72$ $<$ https://doi.org/10.35457/jares.v1i1.50 6>

Irdaf, Irdaf, 'Mobilitas Pencarian Kerja Dan Remitan: Kasus Desa Pojok Kabupaten Kediri, Jawa Timur', Berdikari: Jurnal Pengabdian Masyarakat Indonesia, 1 (2018), 105-12 $<$ http://jurnaljpmi.com/index.php/jpmi 
/article/view/38>

Prastiwi, Finna Dwi, 'The Study of Teacher Talks Used By English Course Teacher of Pare-Kediri in Speaking Class', RETAIN, 3 (2006), 1-5

Primawati, Anggraeni, 'Remitan Sebagai Dampak Migrasi Pekerja ke Malaysia', Sosio Konsepsia, 16 (2017), 209-22

Rahayuningsih, Eni Sri, 'Analisis Pengelolaan Tenaga Kerja Indonesia (TKI) Di Jawa Timur', Media Trend, 1 (2016), 35-48

Ruhamak, M Dian, and Budi Rahayu, 'Pengaruh Word of Mouth Terhadap Purchase Intention Melalui Brand Image pada Lembaga Kursus Bahasa Inggris Dynamic English Course Pare', Ekonika: Jurnal Ekonomi Universitas Kadiri, 1 (2017), 32-33

$<$ https://doi.org/10.30737/ekonika.v1i2. 14>

Sayono, Joko, Indah Wahyu Puji Utami, and Lutfiah Ayundasari, 'Migrant Workers and Socio-Economic Changes', Masyarakat, Kebudayaan dan Politik, 31 (2018), 176-89

Sili Antari, SE, 'Pengaruh Pendapatan, Pendidikan, Dan Remitan Terhadap Pengeluaran Konsumsi Pekerja Migran Nonpermanen Di Kabupaten Badung (Studi Kasus Pada Dua Kecamatan Di Kabupaten Badung)', Piramida, 4 (2008), 20-35

SUGEHA, Az, 'Students'Motivation on Learning English At Toefl Program of Elfast English Course in Pare', Jurnal Ilmiah Mahasiswa FIB, 2 (2015), 45-59 $<$ http://jimbastrafib.studentjournal.ub.ac .id/index.php/jimbastrafib/article/view/ 907>

Sulhan, Moh., 'Nilai Profetis Pendidikan Islam Untuk Menanggulangi Perdagangan Manusia', Nadwa, 6 (2016), 151 $<$ https://doi.org/10.21580/nw.2012.6.2. $585>$

Tirtosudarmo, Riwanto, 'The Indonesian State's Response to Migration', Journal of Social Issues in Southeast Asia, 14 (1999),
212-28 <https://doi.org/10.1355/sj14$1 \mathrm{i}>$

Tirtosudarmo, Riwanto, and Lilis Mulyani, 'Indonesia' s Migrant Workers and Overseas Labor Policy 1', Jurnal Masyarakat dan Budaya, 15 (2011), 1-19

Yulianingsih, Wiwin, Supriyono, Ach Rasyad, and Umi Dayati, "The Involvement of Informal Sector Workers in Society Learning Activities at Kampung Inggris Pare Kediri', Journal of Social Studies Education Research, 9 (2018), 132-44 <https://doi.org/10.17499/jsser.29578>

\section{Online references}

Anonim, 'Remitansi TKI Melalui Kantor Pos Kediri' <http://www.antarajatim.com. remitansi-TKI-melalui-kantor-pos-kediri naik 30 persen $>$ accessed 10 October 2017 \}

Anonim, 'Penempatan TKI tahun 2014, $<$ http://www.bnp2tki.go.id/9801/thn2014 BNP2TKI-mencatat-penempatanTKI-tahun-2014 $>$ \{accessed 4 March 2016\}

\section{Interviews}

Mrs. Rindu (English teachers in Pare), Interview \{Tuesday, 2 February 2016, Thursday, 28 January 2016 Friday, 29 January 29, $2016\}$

Mr Hidayat, (English teacher), Interview \{Saturday, 2 February 2016\}

Mr. Muhsin, (English teachers in Pare), Interview (Friday, 29 January 29, 2016\}

Mr. Oki (English teachers in Pare), Interview \{Wednesday, 10 February 2016\}

Pak De, (Pare citizen/worker), Interview \{Wednesday, 2 February 2016\}

Abdurrahman (Pare leader community), Interview \{Wednesday, 18 May 2016\}

Abdul (Pare citizens/worker), Interview \{Sunday, 1 February 2016\}

Mr. Bejo (English teacher in Pare), interview $\{$ Wednesday, 27 January 2016\} 
Mrs. Azizah (English teacher), Interview \{Tuesday, 2 February 2016\}

Mr. Ismail (English teacher), Interview \{Tuesday, 13 February 2016\}

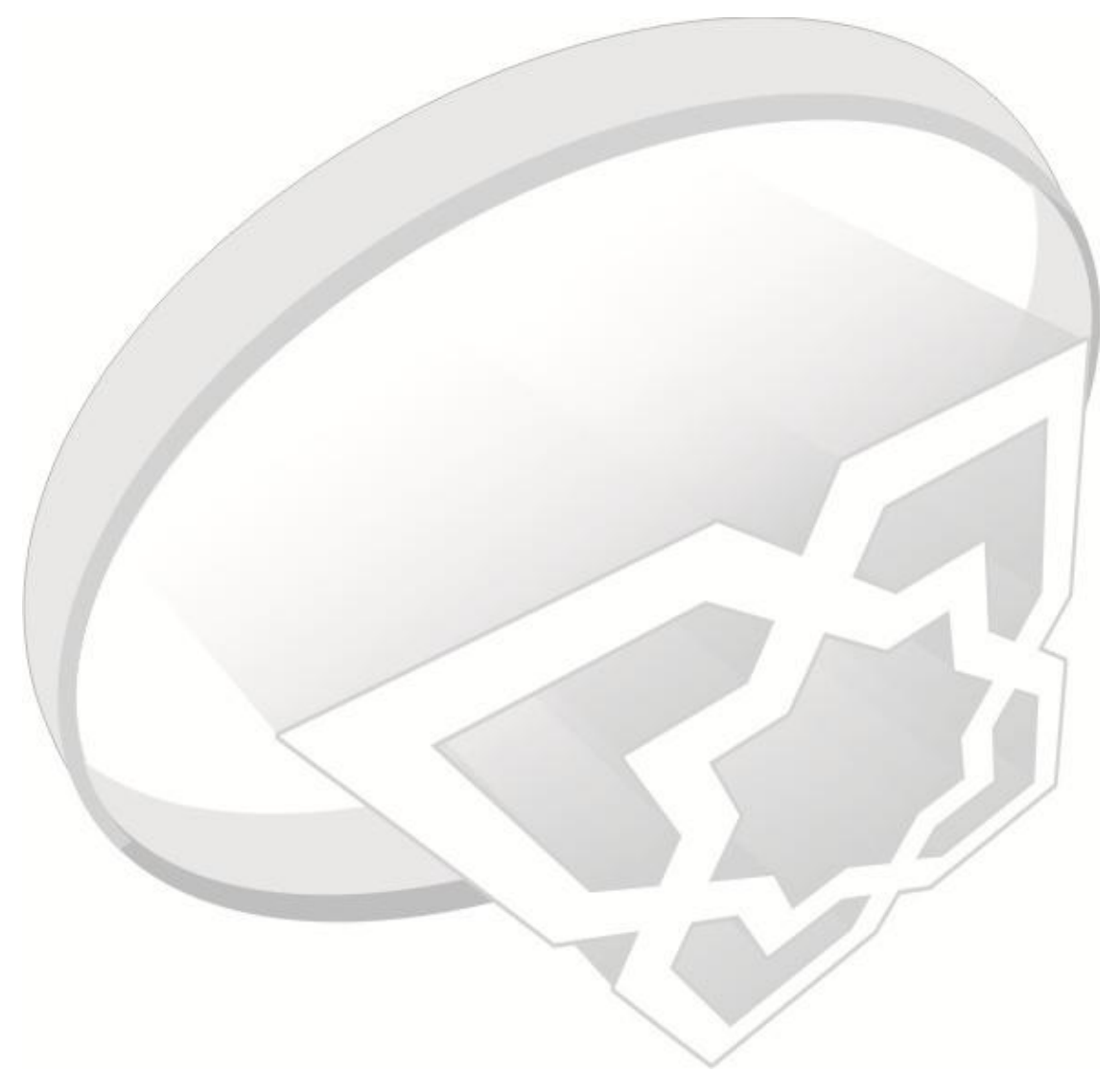

